\title{
SISTEM INFORMASI ABSENSI, PENILAIAN DAN GREAD JUARA KELAS SISWA MENGGUNAKAN DATABASE MYSQL PADA SEKOLAH DASAR PERMATA HARAPAN I BATAM
}

\author{
Sahara, S.Pd., M.Pd.E \\ Program Studi Akuntansi, Akademi Akuntansi Permata Harapan \\ Email : sahara.rara26@gmail.com
}

\begin{abstract}
ABSTRAK
Sistem informasi absensi, penilaian dan gread juara kelas yang menggunakan database MySQL merupakan suatu sistem yang memberikan informasi mengenai hasil belajar siswa secara online yang berupa laporan absensi, penilaian serta penentuan gread juara kelas dengan menggunakan database MySQL yang membantu guru dengan cepat serta akurat dalam hal pengambilan keputusan. Penelitian ini penulis peroleh dari hasil observasi dengan melaksanakan pengamatan secara langsung terhadap objek yang sedang diteliti. Penelitian ini menggunakan tahapan penelitian menganalisa masalah, pengumpulan data dengan cara observasi, studi literatur, dan wawancara. Tujuan dari penelitian ini untuk membangun suatu sistem informasi yang mempermudah dalam menginput absensi siswa, pengecekan serta pelaporan data nilai siswa yang terkomputerisasi. Penelitian telah menghasilkan sebuah sistem penginputan absensi siswa, pengolahan nilai dan penentuan gread juara kelas yang membantu kerja guru dan juga wali kelas secara efektif dan efesien sehingga menghasilkan data yang tepat dan akurat serta mudah untuk diakses sesuai dengan kebutuhan sekolah dasar Permata Harapan I.
\end{abstract}

Kata Kunci: Sistem Informasi, Penilaian, Gread Juara Kelas, MySQL

JURSIMA

Jurnal Sistem Informasi dan Manajemen https://ejournal.giciku.ac.id/

STMIK GICI 


\section{PENDAHULUAN}

Perkembangan teknologi yang ada pada zaman sekarang tidak dipungkiri merubah banyak hal dalam kehidupan kita. Banyak hal yang mulanya tidak bisa dijangkau oleh manusia, sekarang telah diubah dengan didukung oleh teknologi-teknologi canggih sehingga memudahkan manusia itu sendiri dalam banyak hal terutama dalam pendidikan. Pendidikan memegang peranan penting sebagai wahana untuk meningkatkan dan mengembangkan kualitas sumber daya manusia. Dengan perkembangan teknologi yang ada banyak sekolah-sekolah telah memanfaatkan teknologi tersebut sehingga mempermudah pengaksesan informasi baik itu penilaian dan semua yang berhubungan dengan informasi sekolah.

Pada SDS Permata Harapan I Batam masalah yang sering dihadapi yaitu lamanya proses pengolahan data nilai siswa yang pengolahannya masih menggunakan cara konvensional, dimana nilai-nilai ulangan harian, tugas, ujian tengah semester, ujian akhir semester dan leger terkumpul dalam bentuk kertas yang jumlahnya banyak sehingga menyulitkan guru atau wali kelas untuk mengolahnya. Masalah lain yang timbul adalah pencarian data berdasarkan nilai tertinggi untuk menentukan gread juara kelas yang apabila dilakukan dengan manual sistem mencatat di atas kertas, maka akan memakan waktu yang cukup lama, pekerjaan menjadi tidak efesien. Begitu juga dengan absensi siswa masih dilakukan secara manual.

Meskipun faktanya komputer tidak lebih dari sekedar sebuah alat untuk mengolah data, banyak manajer memandangnya sebagai elemen sentral terpenting dalam suatu sistem informasi. Peran sebenarnya adalah menyajikan informasi untuk pengambilan keputusan dan perencanaan serta pengendalian informasi.
Pengertian sistem menurut Kadir (2003:1) dalam buku Pengenalan Sistem Informasi, yaitu: "Sistem adalah sekumpulan elemen yang saling terkait atau terpadu yang dimaksudkan untuk mencapai suatu tujuan”.

Sedangkan menurut Gordon B. Davis Gordon B. (2013:3) Sistem sebagai bagianbagian yang saling berkaitan yang beroperasi bersama untuk mencapai beberapa sasaran atau maksud. Dari beberapa pengertian tersebut dapat diambil kesimpulan bahwa sistem merupakan sekelompok elemen yang saling berhubungan dengan maksud yang sama untuk mencapai suatu tujuan.

Sistem Informasi adalah suatu sistem di dalam suatu organisasi yang mempertemukan kebutuhan pengolahan transaksi harian mendukung fungsi operasi organisasi yang bersifa manajerial dengan kegiatan strategi dari suatu organisasi untuk dapat menyediakan kepada pihak luar tertentu dengan laporanlaporan yang diperlukan.

Dengan menggunakan sistem informasi absensi, penilaian dan gread juara kelas yang terkomputerisasi, maka semua data data tersimpan dengan rapi, pengolahan data yang mudah, informasi dapat dilakukan secara cepat, tepat dan akuran dibandingkan dengan sistem manual yang belum terkomputerisasi.

Oleh sebab itu pemanfaatan teknologi informasi ini sendiri sangat dibutuhkan oleh SDS Permata Harapan I Batam yang mana untuk meningkatkan efesiensi dan produktivitas bagi manajemen pendidikan. Para guru tidak lagi disibukkan dengan pekerjaan yang menggunakan cara yang masih konvensional yang sesungguhya dapat digantikan dengan komputer. Dengan demikian dapat memberikan efesiensi waktu, tenaga serta informasi yang dihasilkan tepat dan akurat. Berdasarkan latar belakang di atas, maka penulis tertarik melakukan penelitian mengenai "Sistem informasi absensi, penilaian dan gread juara kelas siswa menggunakan

https://ejournal.giciku.ac.id/ STMIK GICI 
database MySQL pada SDS Permata Harapan I Batam".

Rumusan masalah dari penelitian ini adalah

1. Bagaimana guru bisa melakukan pengolahan data nilai siswa secara akurat tanpa ada keterlambatan waktu dalam pengolahanya?

2. Bagaimana mengetahui jumlah kehadiran siswa secara rinci dan tepat?

3. Bagaimana membantu guru dalam pengambilan keputusan untuk menentukan juara bagi tiap-tiap kelas?

4. Bagaimana menghasilkan informasi yang tepat waktu, akurat serta bebas dari manipulasi data, baik untuk pihak intern maupun ekstern yang membutuhkan data dalam sistem absensi, penilaian dan gread juara tersebut.

Adapun tujuan dari penelitian ini adalah untuk:

1. Untuk membantu guru dalam melakukan pengolahan data nilai siswa secara akurat dan tepat waktu.

2. Untuk mengetahui jumlah kehadiran siswa secara rinci dan tepat

3. Untuk membantu guru dalam pengambilan keputusan dalam menentukan juara kelas

4. Untuk menghasilkan informasi yang tepat waktu, akurat serta bebas dari manipulasi data.

\section{LANDASAN TEORI}

Menurut Tata Sutabri (2016:46), Sistem informasi adalah suatu sistem didalam suatu organisasi yang mempertemukan kebutuhan pengolahan transaksi harian yang mendukung fungsi operasi organisasi yang bersifat manajerial dengan kegiatan strategi dari suatu organisasi untuk dapat menyediakan

JURSIMA

Jurnal Sistem Informasi dan Manajemen kepada pihak luar tertentu dengan laporanlaporan yang diperlukan.

Suatu sistem pada dasarnya adalah sekelompok unsur yang erat hubungannya satu dengan yang lain yang berfungsi bersamasama untuk mencapai tujuan tertentu. Definisi ini dapat dirinci lebih lanjut tentang pengertian sistem secara umum yaitu:

1. Setiap sistem terdiri dari unsur unsur. Unsur-unsur suatu sistem terdiri dari subsistem yang lebih kecil, yang terdiri pula dari kelompok unsur yang membentuk subsistem tersebut.

2. Unsur-unsur tersebut merupakan bagian terpadu sistem yang bersangkutan. Unsur-unsur sistem berhubungan erat satu dengan yang lain dan sifat serta kerjasama antar unsur sistem tersebut bentuk tertentu.

3. Unsur sistem tersebut bekerjasama untuk mencapai tujuan sistem. Setiap sistem mempunyai tujuan tertentu.

4. Suatu sistem merupakan bagian dari sistem lain yang lebih besar

Pendekatan sistem menekankan komponen akan memudahkan mempelajari suatu sistem untuk tujuan analisis dan perancangan suatu sistem. Ada yang menyebutkan, maksud suatu sistem adalah untuk mencapai suatu tujuan (goal) dan ada yang menyebutkan untuk mencapai suatu sasaran (objectives).

\section{Karakteristik Sistem}

Menurut Rusdiana dan Moch. Irfan (2014:35), "karakteristik sistem yaitu sebagai berikut:

1. Komponen Sistem (Components System)

Suatu sistem terdiri dari sejumlah komponen yang saling berinteraksi, artinya saling bekerja sama membentuk satu kesatuan.

https://ejournal.giciku.ac.id/ STMIK GICI 
Komponen-komponen sistem tersebut dapat berupa suatu subsistem. Setiap subsistem memiliki sifat dari sistem yang menjalankan suatu fungsi tertentu dan mempengaruhi proses sistem secara keseluruhan.

2. Batas Sistem (Boundary System)

Ruang lingkup sistem merupakan daerah yang membatasi antara sistem dengan sistem yang lain atau sistem dengan lingkungan luarnya. Batasan sistem ini memungkinkan suatu sistem dipandang sebagai satu kesatuan yang tidak dapat dipisahkan.

3. Lingkungan Luar Sistem (Environment System)

Bentuk apapun yang ada di luar ruang lingkup atau batasan sistem yang mempengaruhi operasi sistem tersebut disebut lingkungan luar sistem.Lingkungan luar sistem ini dapat bersifat menguntungkan dan dapat juga bersifat merugikan sistem tersebut. Dengan demikian, lingkungan luar tersebut harus tetap dijaga dan dipelihara. Lingkungan luar yang merugikan harus dikendalikan. Kalau tidak, maka akan menggangu kelangsungan hidup dari sistem tersebut.

4. Penghubung Sistem (Interface System)

Media yang menghubungkan sistem dengan subsistem lain disebut penghubung sistem. Penghubung ini memungkinkan sumber-sumber daya mengalir dari satu subsistem ke subsistem lain. Bentuk keluaran dari satu subsistem akan menjadi masukan untuk subsistem lain melalui penghubung tersebut. Dengan demikian, dapat terjadi suatu integrasi sistem yang membentuk satu kesatuan.
5. Masukan Sistem (Input System)

Energi yang dimasukkan ke dalam sistem disebut masukan sistem, yang dapat berupa pemeliharaan (maintenance input) dan sinyal (signal input). Maintenance input adalah energi yang dimasukkan supaya sistem tersebut dapat beroperasi. Signal input adalah energi yang diproses untuk mendapatkan keluaran. Contoh, di dalam suatu unit sistem komputer, program adalah maintenance input yang digunakan untuk mengoperasikan komputernya dan data adalah signal input untuk diolah menjadi informasi.

6. Proses Sistem (Processing System)

Suatu sistem dapat mempunyai suatu proses yang akan mengubah masukan menjadi keluaran, contohnya adalah sistem akuntansi. Sistem ini akan mengolah data transaksi menjadi laporan-laporan yang dibutuhkan oleh pihak manajemen.

\section{Keluaran (Output)}

Merupakan hasil dari energi yang diolah dan diklasifikasikan menjadi keluaran yang berguna dan sisa pembuangan. Keluaran dapat merupakan masukan untuk subsistem yang lain atau kepada supra sistem.

8. Sasaran (Objectives) dan Tujuan (Goal)

Suatu sistem memiliki tujuan dan sasaran yang pasti dan bersifat deterministic. Kalau suatu sistem tidak memiliki sasaran maka operasi sistem tidak ada gunanya. Suatu sistem dikatakan berhasil bila mengenai sasaran atau tujuan yang telah direncanakan.

https://ejournal.giciku.ac.id/ STMIK GICI 
Komponen sistem informasi

Sistem informasi terdiri dari komponen-komponen yang disebut blok bangunan (building block), yang terdiri dari blok masukan, blok model, blok keluaran, blok teknologi, blok basis data, dan blok kendali. Sebagai suatu sistem, keenam blok tersebut masing-masing saling berinteraksi satu dengan yang lainnya membentuk suatu kesatuan untuk mencapai sasaran.

Menurut Sudrajat dalam Yudha (2017:9), "Penilaian adalah penerapan berbagai cara dan penggunaan beragam alat penilaian untuk memperoleh informasi tentang sejauh mana hasil belajar peserta didik atau ketercapaian kompetensi peserta didik". Sedangkan menurut Yuliarto (2014:2) "Penilaian merupakan prosess pengambilan keputusan yang bersifat kualitatif sesuai dengan hasil pengukuran. Penilaian dilakukan berdasarkan kepada tujuan yang ingin dicapai”. Jadi dapat disimpulkan bahwa penilaian adalah proses pengambilan keputusan yang digunakan untuk mengukur pencapaian hasil belajar peserta didik dalam mencapai kompetensi kelulusan yang ditargetkan.

Definisi Database

Menurut Fathansyah (2015), Pemanfaatan basis data dilakukan untuk memenuhi sejumlah tujuan (objektif) sebagai berikut:

1. Kecepatan dan kemudahan (Speed)

2. Efesiensi ruang penyimpanan (Space)

3. Keakuratan (Accuracy)

4. Ketersediaan (Availability)

5. Kelengkapan (Completeness)

6. Keamanan (Security)

7. Kebersamaan pemakaian (Sharability)

JURSIMA

Jurnal Sistem Informasi dan Manajemen
Definisi MySQL (My Structured Query Language)

Menurut Prasetyo (2003), MySQL merupakan salah satu database "server" yang berkembang dilingkungan open source dan didistribusi secara gratis dibawah lisensi GPL (General Public License).

Menurut Nugroho (2013), MySQL adalah sebuah program pembuat dan pengelola database atau yang sering disebut dengan DBMS (Database Management System). Jadi dapat disimpulkan bahwa suatu program yang mengolah database dengan cepat dan menampung jumlah yang besar dan dapat diakses oleh banyak user.

Menurut Riyanto (2003) dalam buku yang berjudul Koneksi Data Melalui Borland Delphi dalam Database MySQL, sebagai software database dengan konsep database modern, MySQL mempunyai banyak kelebihan, seperti:

\section{1) Portability}

MySQL dapat digunakan dengan stabil tanpa kendala yang berarti padaberbagai sistem operasi seperti Linux, Windows, FreeBSD, Mac OS X Server Solaris, Amiga, HP-UX dan masih banyak lagi.

2) Open Source

MySQL didistribusikan secara open source (gratis), di bawah lisensi GPL, sehingga dapat diperoleh dan digunakan secara cumacuma tanpa dipungutbiaya sepeser pun.

\section{3) Multiuser}

MySQL dapat digunakan untuk menangani beberapa user dalam waktu yangbersamaan tanpa mengalami masalah atau konflik. Hal ini memungkinkansebuah database server MySQL dapat diakses client secara bersamaan dalamwaktu yang bersamaan pula.

\section{4) Performance}

Dalam hal performance, MySQL memiliki kecepatan yang cukupmenakjubkan dalam

https://ejournal.giciku.ac.id/ STMIK GICI 
menangani query-query sederhana, serta mampumemproses lebih banyak SQL persatuan waktu.

\section{5) Column Types}

MySQL mendukung tipe kolom (tipe data) yang sangat kompleks, seperti signed/unsigned integer, float, double, char, varchar, text, blob, date, time, datetime, timestamp, year, set, serta enum. Bukan tidak mungkin tipe-tipe datatersebut akan terus dikembangkan oleh pengembang MySQL.

\section{6) Comma and Function}

MySQL mempunyai operator dan fungsi secara penuh yang mendukungperintah SELECT dan WHERE dalam query.

\section{7) Security}

Sekuritas sistem merupakan hal yang sangat diperhatikan pada MySQL.Terbukti dengan adanya beberapa lapisan sekuritas seperti subnet mask, namahost, dan izin ases user dengan sistem perizinan yang mendetail sertapassword terenkripsi.

8) Scalability and Limits

Dalam hal batas kemampuan, MySQL terbukti mampu menangani databasedalam skala cukup besar, dengan jumlah record lebih dari 50 juta dan 60 ribu tabel serta 5 miliar baris. Selain itu, batas indeks yang dapat ditampungmmencapai 32 indeks pada setiap tabelnya.

9) Connectivity

MySQL mampu melakukan koneksi dengan client menggunakan protocolTCP/IP, Unix soket (Unix) atau Named Pipes (NT).

\section{0) Localstation}

Localstation merupakan salah satu kemampuan MySQL dalam mendeteksipesan kesalahan (error code) pada client dengan menggunakan lebih dari duapuluh bahasa. Dengan demikian, pengguna cukup menyesuaikan bahasa yangdigunakan.

\section{1) Interface}

Sama halnya dengan software-software database lainnya MySQL memilikiinterface

\section{JURSIMA}

Jurnal Sistem Informasi dan Manajemen (antarmuka) terhadap berbagai aplikasi dan bahasa pemrogramandengan menggunakan fungsi API (Aplication Prgramming Interface).

12) Client and Tools

$M y S Q L$ dilengkapi dengan berbagai tool yang dapat digunakan untukadministrasi database, dan pada setiap tool yang ada disediakan petunjukonline. Hal ini akan semakin memudahkan pengguna dalam menggunakanMySQL.

13) Structure Tabel

Struktur tabel MySQL cukup baik serta cukup fleksibel, misalnya ketikamenangani ALTER TABLE, dibandingkan dengan database lainnyasemacam PostgreSQL, ataupun Oracle

\section{HASIL DAN PEMBAHASAN}

Perancangan E-Absensi, penilaian dan gread juara kelas sebagai media pengolahan data absen siswa pada SD Permata Harapan I dimulai dari perancangan basis data yang meliputi perancangan-perancangan tabel sesuai kebutuhan data dan penentuan hubungan antar-field (entity relationship) yang ada dalam tabel tersebut. Aplikasi sistem dibuat dengan program MySQL yang terintegrasi dalam XAMPP. Analisis terhadap system yang dilakukan sebelum proses perancangan dilakukan.

Perancangan sistem adalah merancang atau mendesain suatu sistem yang baik, yang isinya adalah langkah-langkah operasi dalam proses pengolahan data dan prosedur untuk mendukung operasi sistem.

\section{Unified Modelling Language (UML)}

Unified Modelling Language (UML) adalah sebuah "bahasa" yang telah menjadi standar dalam industri untuk visualisasi, merancang dan mendokumentasikan sistem piranti lunak.UML menawarkan sebuah

https://ejournal.giciku.ac.id/ STMIK GICI 
standar untuk merancang model sebuah sistem. Dengan menggunakan UML kita dapat membuat model untuk semua jenis aplikasi piranti lunak, dimana aplikasi tersebut dapat berjalan pada piranti keras, sistem operasi dan jaringan apapun, serta ditulis dalam bahasa pemrograman apapun. Adapun UML yang dirancang dalam pembuatan sistem ini sebagai berikut:

\section{Use Case Diagram}

Use Case adalah konstruksi untuk mendeskripsikan bagaimana sistem terlihat dimata pengguna. Sasaran pemodelan Use Case diantaranya adalah mendefinisikan kebutuhan fungsional dan operasional sistem dengan mendefinisikan skenario penggunaan yang disepakati antara pemakai (user) dan pengembang (admin).

\section{Gambar 1. Use Case Diagram}

\section{Keterangan :}

1. Sistem actor Admin, Admin dapat melakukan pengelolaan/manajemen terhadap data-data yang meliputi pengelolaan data siswa (tambah data siswa, edit data siswa dan hapus data siswa), pengelolaan data guru (tambah

data guru, edit data guru dan hapus data guru), pengolahan data kelas (tambah kelas, edit kelas, dan hapus kelas), dan pengolahan data mata pelajaran (tambah mata pelajaran, edit mata pelajaran, dan hapus mata pelajaran).

2. Sistem actor Guru

a. Guru dapat melakukan penginputan data tehadap data-data yang meliputi input data absen siswa (inputa data hadir, izin, sakit dan alfa/tanpa keterangan).

b. Guru dapat melihat profil atau akun yang berisi tentang data diri guru pemilik akun.

3. Sistem actor Siswa

a. Untuk aktor siswa dapat melakukan hal-hal yang meliputi (profil atau data diri siswa dan laporan data nilai sendiri).

\section{Class Diagram}

Class diagram adalah sebuah spesifikasi yang akan menghasilkan sebuah objek dan merupakan inti dari pengembangan dan desain berorentasi objek. Class diagram juga mengambarkan struktur suatu sistem dengan menunjukkan class dan hubungannya, adapun interaksinya dapat dilihat pada gambar 


\section{Gambar 2. Class Diagram}

\section{Activity Diagram login Admin}

Activity diagram login admin menggambarkan bagaimana admin melakukan login dan memeriksa apakah masih ada field yang kosong, jika masih ada field yang kosong maka sistem akan menampilkan pesan pemberitahuan bahwa anda gagal login dan admin akan mengisi field pada form login admin, sedangkan jika field sudah terisi maka sistem akan memeriksa data login dan jika data login salah maka sistem akan menampilkan anda gagal login dan akan kembali ke form login admin sedangkan jika field benar, sistem akan menampilkan halaman admin, interaksi ini dapat dilihat pada gambar 3.4.

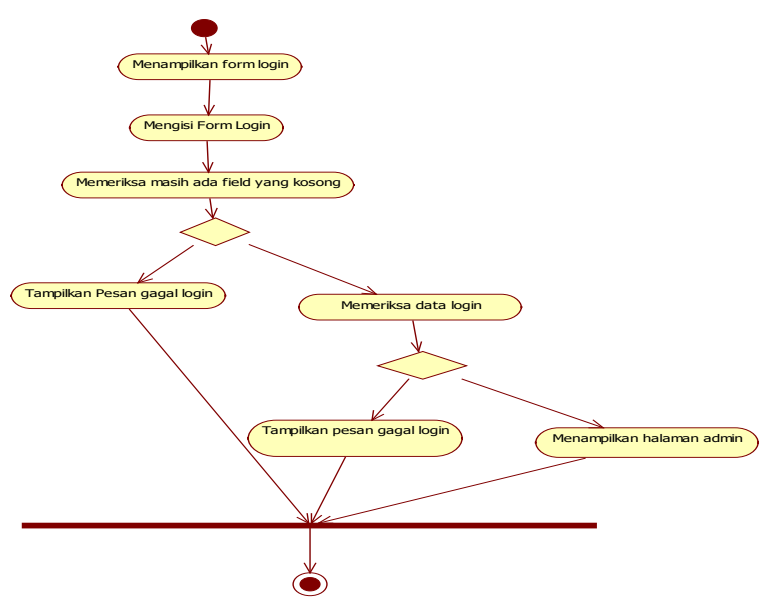

Gambar 3. Activity Diagram Login Admin

Activity Diagram login guru

Activity diagram login guru menggambarkan bagaimana guru melakukan login, dengan memasukan username dan password yang sudah terdaftar pada list registrasi Guru interaksi ini dapat dilihat pada gambar 4.

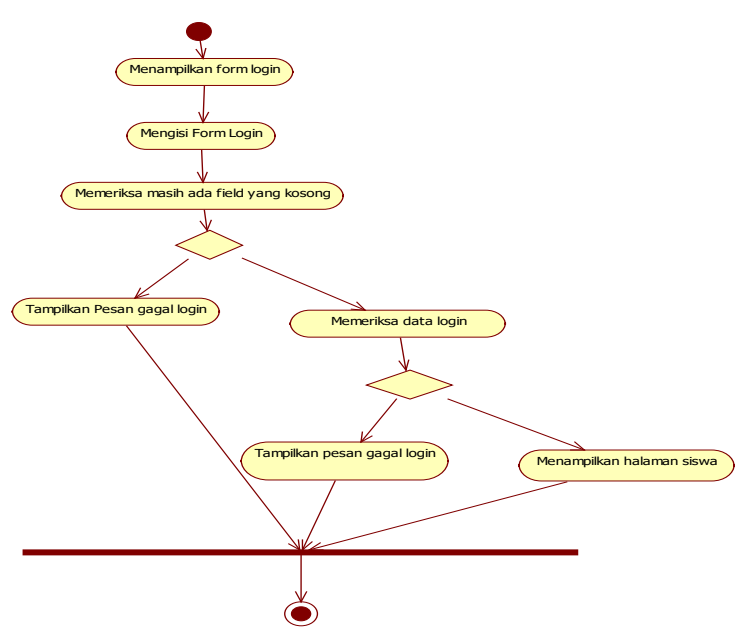

Gambar 4. Activity Diagram Login Guru
JURSIMA

Jurnal Sistem Informasi dan Manajemen https://ejournal.giciku.ac.id/ STMIK GICI 
Tahap Pengujian Website

Pengujian terhadap sistem dilakukan untuk mengetahui sejauh mana sistem informasi yang dirancang dapat mengatasi masalah, serta untuk mengetahui hubungan antar komponen sistem. Dengan demikian langkah-langkahnya sebagai berikut :

1. Setelah melakukan tahap penginstallan Xampp dan pembuatan database forum, kemudian buka tab baru pada browser dan ketikan http://localhost/absensi/index.php .

2. Layout Home

Layout home atau menu utama adalah halaman yang pertama kali muncul saat alamat situs diakses. Pada halaman depan terdapat form login. Gambar layout menu utama dapat dilihat seperti pada gambar 5

\section{Gambar 5. Layout Home}

3. Layout Login Admin

Layout login admin beirisikan form login yang dapat di lihat pada gambar 6

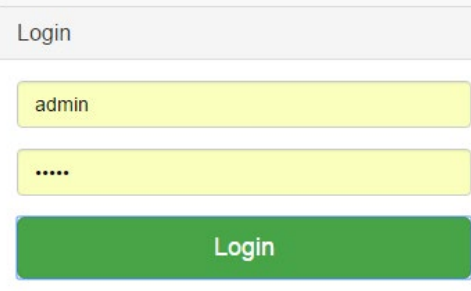

\section{Gambar 6. Layout Login Admin}

4. Layout Home Admin Layout home admin berisikan dibagian header yaitu : user, tombol logout dan tanggal. Sebelah kiri terdapat menu yaitu : data siswa, data guru, data kelas dan data mata pelajaran dapat di lihat pada gambar 6

\section{Gambar 6 Layout Home Admin}

5. Layout Admin Form Input Data Siswa Layout berisikan form input data siswa yang dapat di lihat pada gambar 7

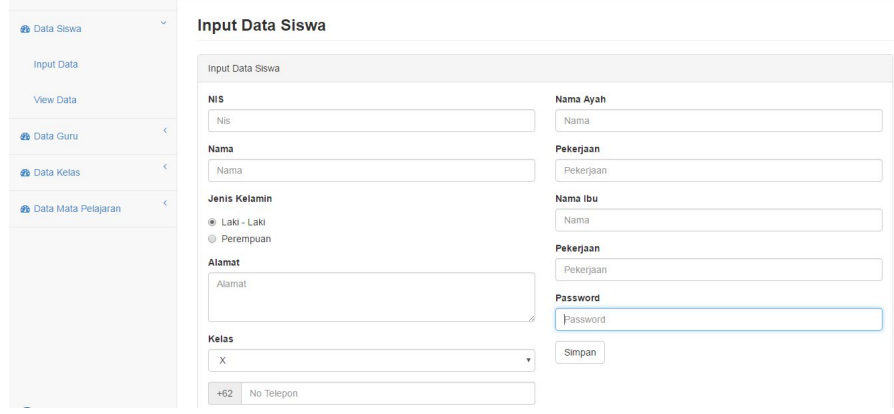

\section{Gambar 7 Layout Admin Input Data Siswa}

\section{Layout Admin Input Data Guru} Layout ini berisikan form input data guru dapat dilihat pada gambar 8 https://ejournal.giciku.ac.id/ STMIK GICI 
Input Data Guru

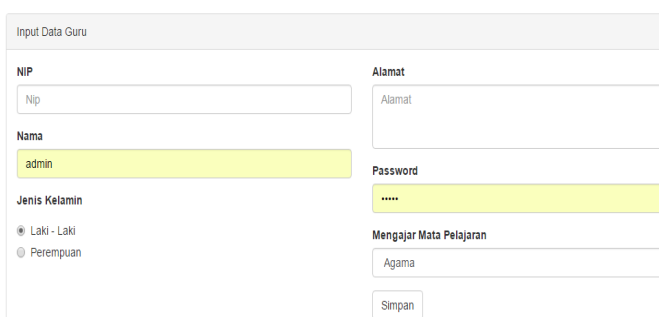

Gambar 8 Layout Admin Input

Data Guru

7. Layout Admin Input Kelas

Layout ini berisikan form input kelas dapat di lihat pada gambar 9

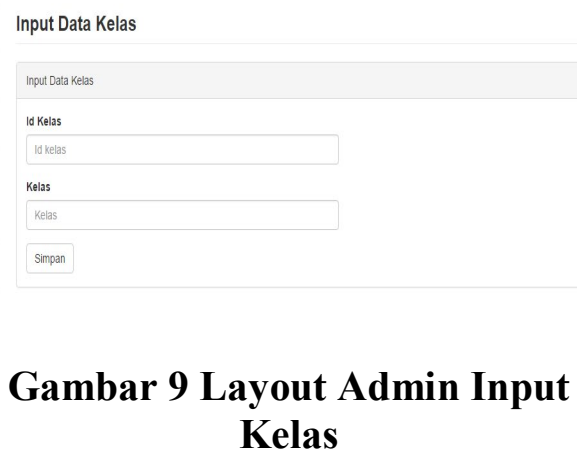

8. Layout Admin Input Data Mata Pelajaran

Layout berisikan form input data mata pelajaran dapat di lihat pada gambar 10

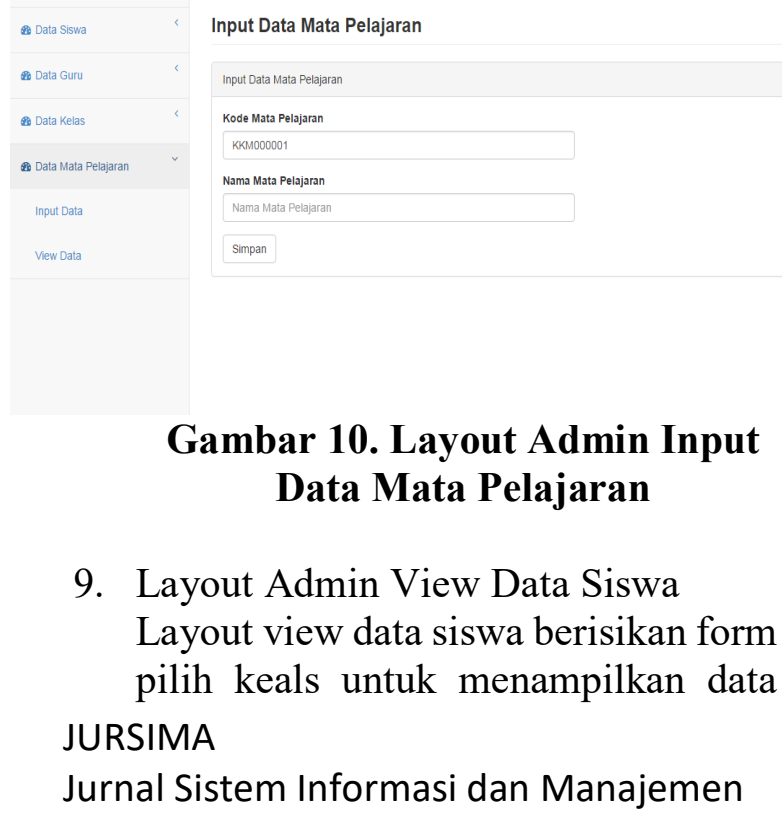

siswa perkelasnya dapat di lihat pada gambar 11

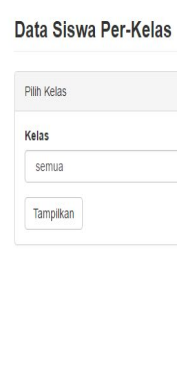

\section{Gambar 11 Layout Form View Data} Siswa Perkelas

Dilanjutkan dengan menekan tombol tampilkan untuk menampilkan data siswa dapat dilihat pada gambar 12

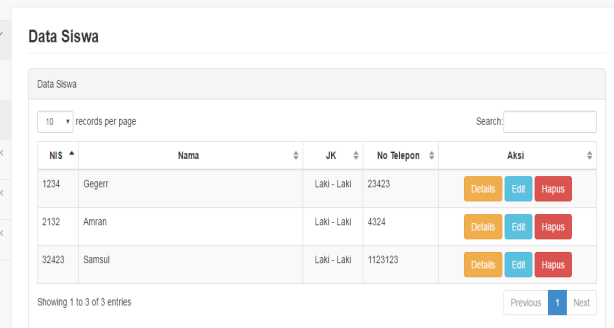

\section{Gambar 12 Layout View Data Siswa Perkelas}

10. Layout Admin View Data Guru

Layout view data guru berisikan form pilih mata pelajaran untuk menampilkan data guru permata pelajaran yang diajarkan dapat di lihat pada gambar 13

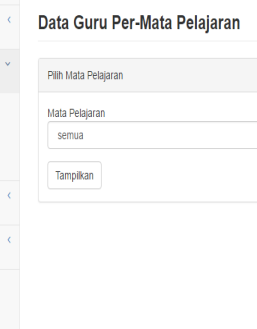

Gambar 13 Layout Form View Data Guru Permata Pelajaran

https://ejournal.giciku.ac.id/ STMIK GICI 
ISSN $2338-1523$

E-ISSN $2541-576 \mathrm{X}$

Volume 7 No. 1

Mei 2019

Dilanjutkan dengan menekan tombol tampilkan untuk menampilkan data guru dapat dilihat pada gambar 14 .

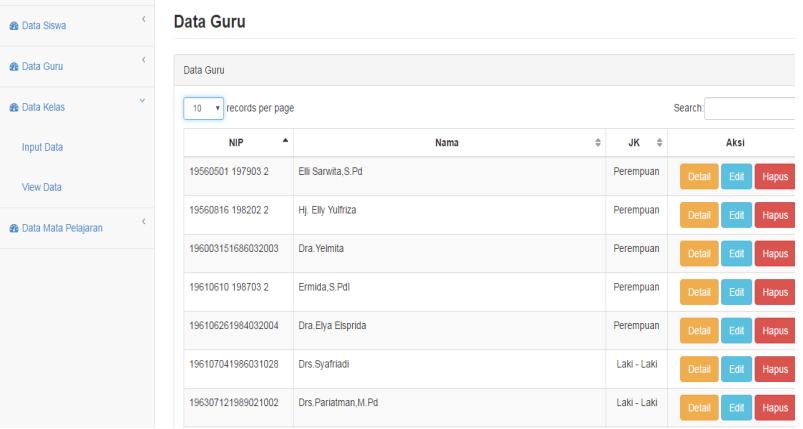

Gambar 14 Layout View Data Guru

11. Layout Admin View Data Mata Pelajaran

Layout admin view data mata pelajaran berisikan data semua mata pelajaran yang ada yang dapat dilihat pada gambar 15

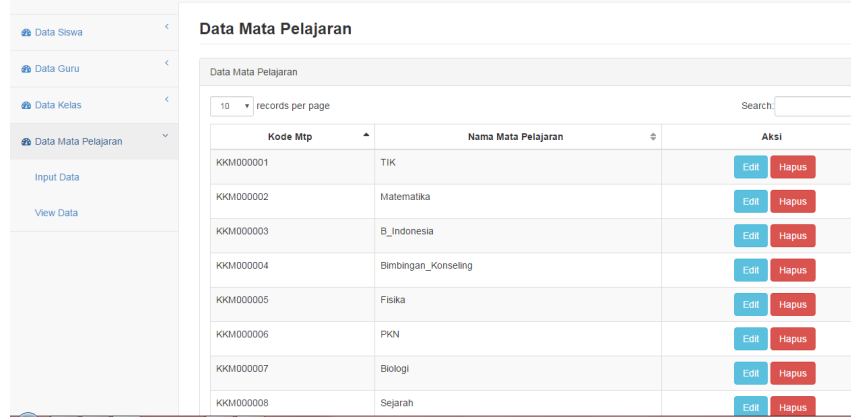

Gambar 15 Layout Admin View

Data Mata Pelajaran

12. Layout Login Guru

Layout login guru berisi form login dapat di lihat pada gambar 16

\section{Gambar 17 Layout Home Guru}

14. Layout Guru Input Data Absensi Layout Input data absensi berisikan form pilih kelas dan mata pelajaran guru yang melakukan login serta tanggal melakukan penginputan data absensi dapat di lihat pada gambar 18

Input Data Absensi

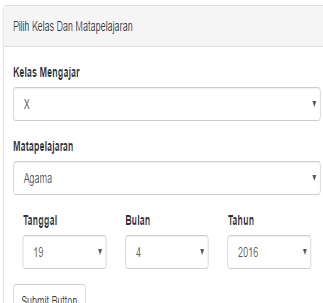

Gambar 18 Layout Form Input Absensi

Dilanjukan dengan menekan tombol submit buton untuk menampilkan form input absensi siswa seperti pada gambar 19
JURSIMA

Jurnal Sistem Informasi dan Manajemen https://ejournal.giciku.ac.id/ STMIK GICI 


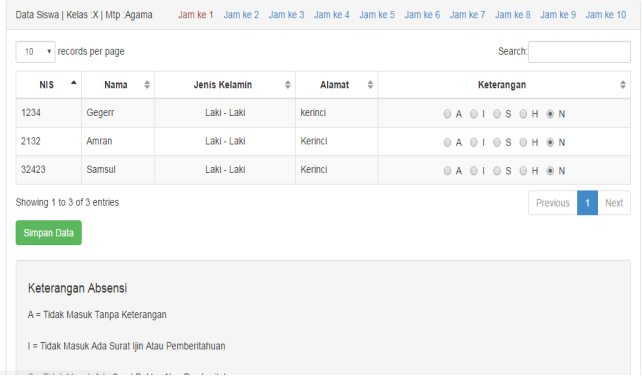

\section{Gambar 19 Layout Input Absensi}

\section{Layout Guru Input Data Nilai}

Layout Input data nilai berisikan form pilih kelas dan mata pelajaran guru yang melakukan login serta tanggal melakukan penginputan data nilai dapat di lihat pada gambar 20

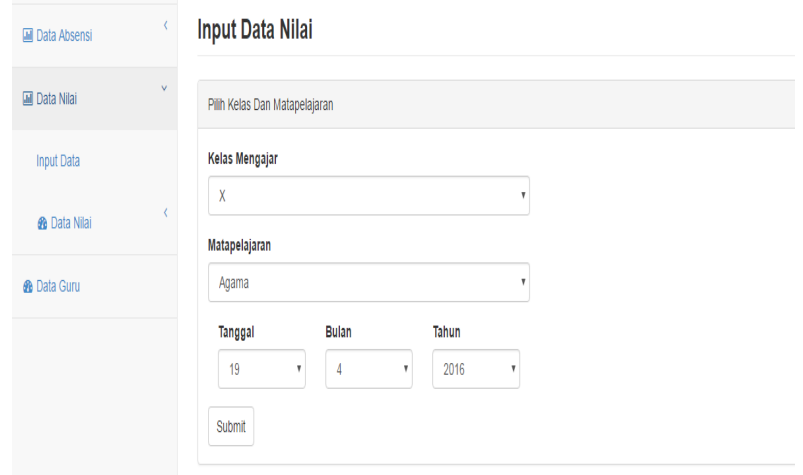

\section{Gambar 20 Layout Form Input Nilai}

Dilanjukan dengan menekan tombol submit untuk menampilkan form input nilai siswa seperti pada gambar 21

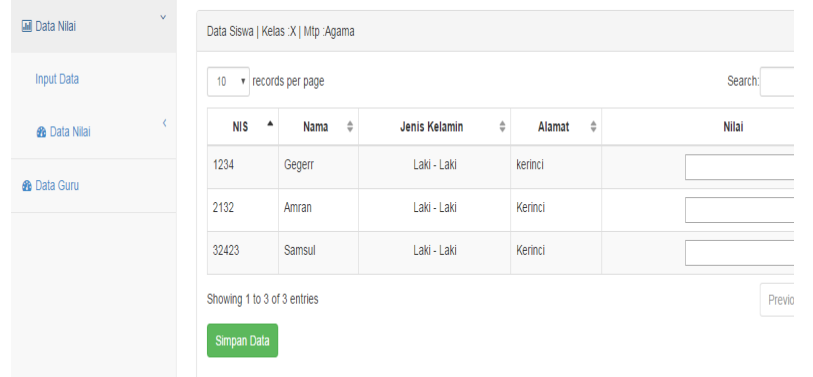

\section{SIMPULAN DAN SARAN}

Kesimpulan dari hasil dan pembahasan di atas, bahwa aplikasi absensi, penilaian dan gread juara kelas pada SD Permata Harapan I sudah terbentuk dengan menggunakan bahasa pemrograman PHP dan menggunakan database MySQL. Aplikasi ini dapat mebantu guru dalam hal pengolahan data absensi dan nilai siswa dengan cepat dan akurat serta membantu guru dalam hal pengambilan keputusan untuk menentukan juara kelas.

Agar penerapan sistem yang baru ini dapat berjalan dengan baik maka berikut disampaikan beberapa saran-saran dalam penggunaan sistem yang baru ini :

a. Modul-modul yang dipakai perlu dikembangkan lagi untuk memperkaya fasilitas yang ada pada aplikasi ini.

b. Tidak adanya fitur pemberitahuan tentang siapa dan kapan melakukan aktivitas penginputan data, sehingga menyulitkankan untuk mengetahui kapan dan siapa yang melakukan penginputan data.

c. Menambahkan fitur-fitur dan tampilan yang menarik agar siswa lebih tertarik untuk melihat pada modul siswa sebaiknya ditambahkan menu lain, seperti halnya menampilkan laporan tentang nilai siswa. Dengan adanya hal tersebut dapat menjadi motivasi bagi siswa untuk lebih giat belajar.

\section{UCAPAN TERIMA KASIH}

Penulis ucapkan terima kasih kepada temanteman dan dosen Sekolah Tinggi Manajemen dan Informatika GICI yang telah membantu sehingga penelitian ini dapat diselesaikan dengan baik.

\section{Gambar 21 Layout Input Nilai}

JURSIMA

Jurnal Sistem Informasi dan Manajemen https://ejournal.giciku.ac.id/

STMIK GICI 


\section{DAFTAR PUSTAKA}

Davis, Gordon B. 2013. Kerangka Dasar Sistem Informasi Manajemen. Palembang: Maxikom.

Fathansyah. 2015. Basis Data Revisi Kedua. Bandung:Informatika Bandung.

Kadir, Abdul. 2003, Pengenalan Sistem Informasi, Andi, Yogyakarta.

Nugroho, Bunafit. 2013. Dasar Pemograman Web PHP - MySQL dengan Dreamweaver. Yogyakarta : Gava Media

Prasetyo. Didik. 2003. Tip dan Trik Kolaborasi PHP dan MySQL. PT. Elex Media Komputindo. Jakarta.

Riyanto, 2003, Koneksi Data Melalui Borland Delphi dengan Database MySQL, PT Elex Media Komputindo, Jakarta.

Rusdiana, M., \& Moch. Irfan, S. M. (2014). Sistem Informasi Manajemen. Bandung: Pustaka Setia.

Tata Sutabri. "Analisis Sistem Informasi”. Yogyakarta : Andi, 2016

Yudha, Surya Indra. 2017. "Implementasi Web Service untuk Pengolahan Nilai Raport Siswa SMK Kesehatan Sadewa".

Yogyakarta: Eprints Akakom Yogyakarta Tahun 2017.

Yuliarto, Hari. 2014. "Memahami Tes, Pengukuran dan Penilaian untuk Pengembangan Instrumen Ranah Psikomotor".UNY 